\title{
CHOLESTEROL LEVEL AS PREDICTING OF URIC ACID INCREASE IN ELDERLY
}

\author{
Nugroho Susanto \\ Faculty of Public Health, Respati University of Yogyakarta
}

\begin{abstract}
Uric acid cause inflammation accompanied deformity knees and legs. Elderly increase from 841 million in 2013 to more than 2 billion in 2050. Prevalence of uric acid in Asia regions the lowest Papua New Guinea 1\% highest Marshall Islands $85 \%$ and Indonesia 18\%. Uric acid is main factor predicting kidney failure. The study objective to identify risk factors for elderly uric acid in ordering impacted of volcano areas in Sleman district. Study design were used cross sectional. Population study is elderly under Pakem center health service age 50 - 95 years ordering inclusion and exclusion criteria. Sample was required 66 elderly. Blood sample $5 \mathrm{ml}$ with aseptic with parameter by Easy Touch GCU. Data were collecting by 2 enumerator ordering Pakem center health service. Data were analyzed by SPSS versi 20 with statistic test linear

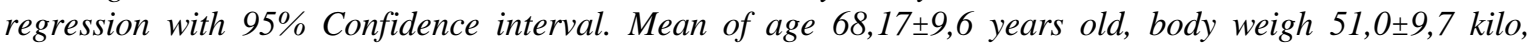
systole blood pressure $141,97 \pm 0,3 \mathrm{mmHg}$, diastolic blood pressure $75,15 \pm 10,2 \mathrm{mmHg}$, cholesterol $194,9 \pm 49,2 \mathrm{mg} / \mathrm{dl}$, uric acid 4,9 $\pm 1,3 \mathrm{mg} / \mathrm{dl}$. Age have been predicting $\beta=0,056$, body weigh $\beta=0,058$, systole blood pressure $\beta=0,07$, diastole blood pressure $\beta=0,08$, cholesterol $\beta=0,21$, glucose $\beta=0,07$ being uric acid for elderly. Above normal average of blood pressure, cholesterol level, uric acid. Cholesterol level is main factor predicting of uric acid.
\end{abstract}

Keyword: Uric acid, cholesterol, glucose, elderly.

\begin{abstract}
Asam urat menyebabkan inflamasi dan kerusakan sendi lutut dan kaki. Usia lanjut meningkat dari 841 juta tahun 2013 menjadi lebih dari 2 juta tahun 2050. prevalensi asam urat di asia terrendah papuanugini $1 \%$, tertinggi di Marshall island 85\% dan Indonesia 18\%. Tujuan penelitian mengetahui model risiko pada lansia terkait asam urat di wilayah dampak gunung berapi Sleman Yogyakarta. Rancangan penelitian dengan cross sectional. Populasi lansia di puskesmas Pakem yang berusia antara 50 - 95 tahun memenuhi kriteria inklusi dan kriteria eklusi. Sampel sebesar 66 lansia. Sampel darah $5 \mathrm{ml}$ dengan teknik antiseptik dan dianalisis dengan alat Easy Touch GCU. Pengambilan data oleh petugas perawat di Puskesmas Pakem sebanyak 2 orang. Analisis data dilakukan dengan SPSS versi 20 dengan uji regresi linier dengan kepercayaan $95 \%$ CI : $\alpha=0,05$. Rerata usia subjek $68,17 \pm 9,6$ tahun, berat badan rerata 51,0 $\pm 9,7$ kilo, tekanan darah sistole

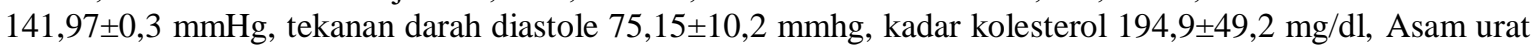
$4,9 \pm 1,3 \mathrm{mg} / \mathrm{dl}$. Umur memprediksi $\beta=0,056$, berat badan $\beta=0,058$, tekanan darah sistol $\beta=0,07$, tekanan darah diastole $\beta=0,08$, kolesterol $\beta=0,21$, kadar gula darah $\beta=0,07$ terhadap kejadian asam urat pada lansia. Rerata diatas normal tekanan darah, kadar kolesterol, kadar asam urat. Kadar kolesterol merupakan faktor berkontribusi paling besar dalam memprediksi asam urat pada lansia.
\end{abstract}

Kata kunci: Asam urat, kolesterol, gula darah, lansia. 


\section{INTRODUCTION}

Uric acid is the residual metabolism result of purine that food consumed. ${ }^{1}$ Accumulation of uric acid can trigger gout which developing arthritis. Accumulation of uric acid cause inflammation accompanied deformity knees and legs. ${ }^{2}$ Uric acid is the end result of purin metabolism. Metabolism purine difficult to dissolve water, but the blood uric acid is dissolved in the form of sodium.

World population ageing 2013 estimate that elderly currently the fastest-growing of the population. Elderly expected increase from 841 million in 2013 to more than 2 billion in 2050. ${ }^{3}$ Based The United States estimate more than 5.7 million people incident of uric acid. The incidence of uric acid up to $46 \%$ and is predicted in $2030^{\text {th }}$ to 8 million people. ${ }^{4}$ Prevalence uric acid in Asia regions total of 24 countries, that the lowest Papua New Guinea 1\% and highest Marshall Islands $85 \%{ }^{5}$. Study in Sydney ${ }^{6}$ Australia that prevalence of hyperuricemia was $22.2 \%$. Prevalence uric acid in Indonesia $18 \% .^{5}$

Previous study in Korea that average rate of hypercholesterolemia $36 \% .^{7}$ Study in China ${ }^{8}$ that range of risk factors mortality of elderly including obesity, hyperglycemia, high blood pressure, high triglycerides, and cholesterol. Purine metabolism dissolved under ph >7. Increase $100 \mathrm{mg} / \mathrm{day}$ consumption were increasing cholesterol $2-3 \mathrm{mg} / \mathrm{dl}$. Consuming fiber and vitamins were reduce cholesterol synthesis in the blood. ${ }^{2}$ Previous study result ${ }^{9}$ that study that first, uric acid levels were positively associated with serum TG, TC, LDL cholesterol and the ratio of TG to HDL cholesterol. In other study, we found a positive association with triglycerides and LDL-cholesterol and a negative one with HDL-cholesterol. ${ }^{10}$ The study objective to identify risk factors for elderly uric acid in ordering impacted of volcano areas in Sleman district.

\section{METHOD}

Study design with a cross sectional. Population study as elderly (aged 50-95 years) who visited for an annual health examination in Puskesmas Pakem during Desember 2019 who elderly in inclusion and exclusion criteria.

Sample frame were collected base on medical record elderly have visited Puskesmas Pakem during December 2019. Sample was collected as 66 elderly with systematic random sampling. Participant include study were invited to health check-up in Puskesmas Pakem. Study variable such as independent variable age, weigh, systolic blood pressure, diastolic blood pressure, glucose level, cholesterol level and dependent variable is uric acid.

Blood sample were require sample venous blood $(5 \mathrm{~mL})$ each participant under strict aseptic precautions. Blood serum was separated for analysis of biochemical parameters. Glucose, 
cholesterol and uric acid levels were analysis with "Easy Touch GCU". Data were collected for age with popullation card data. Weight data were collected with "Xiaomi Mi Smart Scale" by calibrated. Blood pressure systole and diastole was measured twice in the right arm of subjects who had been resting for at least $10 \mathrm{~min}$ in a seated position using a "omran blood pressure monitor".

Data were collecting with 2 enumerator have been certificate of health ministry from Puskesmas Pakem and 1 lecturer education staff. Before data collecting were skills training enumerator for 2 day. Training activities to ensure validity and reliability so same perception related procedure for checking blood pressure, glucose level, cholesterol level and uric acid level. Statistical analysis was performed using IBM SPSS version 20. Results are expressed as mean \pm standard deviation (SD). The relationship between variable cholesterol and other with uric acid were assessed by linear regression. For assess correlation variable independent and dependent were analysis with Pearson's correlation coefficients, $P$-value less than 0.05 was considered to be statistically significant.

\section{RESULTS}

Based data analysis of 66 elderly included with univariate, bivariate and multivariate. Variable were analyzed included gender, age, body weight, systolic and diastolic blood pressure, glucose level, cholesterol level and uric acid level. The results of data analysis are shown in the following table 1:

Table 1. Prediction of Variable Body Weight, Systole and Diastole Blood Pressure, Glucose, Cholesterol for Uric Acid Elderly

\begin{tabular}{lccccccc}
\hline Variable & $\mathbf{N}$ & Mean & SD & $\boldsymbol{\beta}$ & constant & $\mathbf{R}^{\mathbf{2}}$ & $\mathbf{P}$ \\
\hline Age & 66 & 68,17 & 9,6 & 0,236 & 2.610 & 0,056 & 0,056 \\
Weight & 66 & 51 & 9,7 & 0,24 & 3,183 & 0,058 & 0,052 \\
Systole & 66 & 141,97 & 0,3 & 0,081 & 4,034 & 0,007 & 0,517 \\
Diastole & 66 & 75,15 & 10,2 & $-0,087$ & 5.791 & 0,008 & 0,487 \\
Cholesterol & 66 & 137,7 & 57,4 & 0,466 & 2,38 & 0,217 & 0 \\
Glucose & 66 & 194,9 & 49,2 & 0,082 & 4,64 & 0,007 & 0,511 \\
Uric acid & 66 & 4,9 & 1,3 & - & - & - & - \\
\hline
\end{tabular}

Table 1 show the various of characteristic of participant categorized on 66 sample that $\mathrm{A}$ high average of age $68.17 \pm 9.6$ years. This condition based in aging criteria is post elderly. Average of body weight $51.0 \pm 9.7 \mathrm{~kg}$, it categorical condition. Average of systolic blood pressure is $141.97 \pm 0.3 \mathrm{mmHg}$, which categorical is high blood pressure. Average of diastolic blood pressure is $75.15 \pm 10.2 \mathrm{mmHg}$, which condition is lower. A high serum total cholesterol $194.9 \pm$ $49.2 \mathrm{~mm} / \mathrm{dl}$, which categorical is normal high. Mean of uric acid $4.9 \pm 1.3 \mathrm{~mm} / \mathrm{dl}$, which condition is normally uric acid. 
Analysis regression of 66 samples for correlation uric acid that age no significant correlation with uric acid $p=0,056$. no significant weight correlation uric acid $p=0,052$. Systolic blood pressure no significant related uric acid $\mathrm{p}=0,517$. Diastolic blood pressure no significant correlation with uric acid $\mathrm{p}=0,487$. Glucose level no significant correlation with uric acid $\mathrm{p}=$ 0,511. Cholesterol level significant correlation with uric acid $p=0,000$.

Based on table 1, show age was predicted uric acid 0.056 or $5.6 \%(\mathrm{R} 2=0,056)$ to have uric acid disorder for elderly. Weight has predicted $5.8 \%(\mathrm{R} 2=0,058)$ have uric acid for elderly. Systolic blood pressure predicting $0.7 \%(\mathrm{R} 2=0,007)$ uric acid for elderly. Diastole blood pressure was predicting $0.8 \%(\mathrm{R} 2=0,008)$ uric acid for elderly. Glucose level has predicting $0.7 \%(\mathrm{R} 2=$ 0,007 ) uric acid for elderly. Cholesterol level predicting uric acid 21,7\% ( $\mathrm{R} 2=0,217$ ). Based Multivariate analysis that variable highest contributing for uric acid is cholesterol.

Based multivariate analysis that factor contributing increasing uric acid for elderly which increased of age every years was increasing uric acid $0,236(\beta=0,236)$. Increase weigh $1 \mathrm{~kg}$ was increase uric acid 0,24 $(\beta=0,240)$. Systolic blood pressure increase $1 \mathrm{mmHg}$ was increased uric acid 0,081 $(\beta=0,081)$. Diastolic blood pressure increase $1 \mathrm{mmHg}$ was decrease uric acid 0,087 ( $\beta$ $=0,081)$. Total cholesterol increase $1 \mathrm{~mm} / \mathrm{dl}$ was increased uric acid $0,446(\beta=0,446)$. Increase glucose level $1 \mathrm{~mm} / \mathrm{dl}$ was increased uric acid $0,082(\beta=0,082)$. Based result that main factors dominant predicting uric acid is cholesterol.

\section{DISCUSSION}

Study result that average of elderly age included categorical post elderly. Compare previous study ${ }^{11}$ that average age almost same. This condition reported that in Yogyakarta province highest life time population compare other province in Indonesia.

Mean weight of elderly with normal categories. Compare other study relative same. Based systolic blood pressure with categorical high compare WHO criteria for elderly (under 140,0 $\mathrm{mmHg}$ ). ${ }^{3}$ It compare to other studies is relative normal. Study difference compare previous study ${ }^{12}$ That difference caused by condition of elderly an increase average blood pressure. Who conducted a review of uric acid that average blood pressure was relatively normal. This situation could be due to lower age of elderly compare. ${ }^{13}$ The blood pressure more higher for elderly. Different result study were also shown who conducted a study of uric acid on 8.662 subject means of blood pressure was lower than this study. ${ }^{13}$

Cholesterol level with high categories, compare other study ${ }^{14}$ have different result that low cholesterol level for elderly. different caused this study with high average of age than other.

Glucose level (194.9 \pm 49.2$)$ it is above of normal. Glucose higher caused factors age 68.17 \pm 9 .6 condition build increase glucose level. Previous study ${ }^{13}$ Conclude that increase of age to be related glucose intolerance cause in-balance of insulin produce. 
Mean of uric acid with normal categories previous study ${ }^{15}$ that 3591 subjects prevalence of hyper-uremia only $17.5 \%$. It condition caused that average of weight normal result. Weight one of indicator for cholesterol level. Previous study ${ }^{16}$ That increasing uric acid is followed increasing weight loss index and is a prediction of an high uric acid. Elderly is potential for weight loss caused condition food intake in-balance.

Study result that age contribution increase uric acid but no significant correlation. It caused average of body weight participant in normal condition. Increase of age doesn't in order increasing of body weight. Previous study shown that ${ }^{5}$ no significant correlation age with uric acid $p=0,19$. It condition that uric acid caused other factors such as lipid.

Weight contribution increase uric acid, but no significant correlation. It is condition that average of weight participant with normal categories. Compare previous study have been differences that previous study ${ }^{16}$ fat and body weight level are factors associated with hyperuremia.

Conducted a study in Malaysia found that were associated with cholesterol $\mathrm{p}=0.035$, low lipoprotein cholesterol $\mathrm{p}=0.019^{17}$. Study ${ }^{12}$ that factors dominant for uric acid as BMI (Body Mass Index) OR $1.73(1.29-2.32)$.

Systole blood pressure contribution increase uric acid, in other diastole decrease uric acid, but no significant contributing for uric acid. Condition caused that average of blood pressure with normal categories.

Previous study conducted that hyper-uremia was significantly related to blood pressure systolic and diastolic $\mathrm{p}<0.001 .{ }^{18}$ Previous study ${ }^{17}$ concluded that conditional of hypertension are related to uric acid. Previous study ${ }^{19}$ that 3591 subjects free of hypertension for uric acid prediction that subject with hypertension in $(20.7 \%)$. Differences result caused this study average blood pressure in normal condition, other more higher.

Glucose level contributing increase uric acid but, no significant. It condition caused average of body weight relative normally. Previous study ${ }^{13}$ that people from 50 years and above are more prone to increase glucose. Study ${ }^{20}$ has been shown that rats administered with uric acid exhibited glucose intolerance, which were probably mediated by hypothalamus inflammation and neuroendocrine alterations as uric acid produces.

Study shown that cholesterol level contributing significant increase uric acid. It caused that uric acid is residual end product of purine metabolism both from food consumed and protein breakdown. Food consumed over a component of lipid fractions such as more accurate markers of dyslipidemia.

Previous study shown that significant predicting uric acid elderly such as cholesterol level. Previous study ${ }^{21}$ conducted a review that cholesterol related uric acid level. Study ${ }^{7}$ shown that 
obesity significant related cholesterol. Study ${ }^{9}$ that positively associated with serum cholesterol and uric acid. Food consumed imbalance and control factor increased obesity. It condition lipid pathogenesis thus dyslipidemia.

Based regression analysis showed that dominant factor affecting uric acid is cholesterol level. Previous study ${ }^{22}$ total cholesterol level can be influenced by nutrition intake such as fatty food. Cholesterol level are dominant factors in increasing uric acid in elderly.

Cholesterol caused of malnutrition condition. Over consumed increased fat and body weight. It is lipid produce. Study ${ }^{23,}{ }^{24}$ fat and body weight level are factors associated with hyperuremia. Previous study ${ }^{2}$ concluded that accumulation of uric acid in the body can trigger gout.

Study $^{15}$ that LDL-C>100 mg/dl, triglyceride $>150 \mathrm{mg} / \mathrm{dl}$, HDL-C $\geq 40 \mathrm{mg} / \mathrm{dl}$ were significant predictors of vascular complication such as purine. Residual of end product of purine metabolism both from food consumed and protein breakdown ${ }^{25}$. Food consumed over a component of lipid fractions and markers of dyslipidemia. Purine overlap metabolism is makers of uric acid.

\section{CONCLUSIONS}

Blood pressure, cholesterol, uric acid level are relatively high for elderly. The dominant factor predicting uric acid elderly is blood cholesterol levels.

\section{REFERENCE}

1. Lee J, Hong YS, Park SH, Kang KY. High serum uric acid level is associated with greater handgrip strength in the aged population. Arthritis Res Ther. 2019;21(1):1-10.

2. Wang H, Zhang H, Sun L, Guo W. Roles of hyperuricemia in metabolic syndrome and cardiac-kidney-vascular system diseases. Am J Transl Res. 2018;10(9):2749-63.

3. United Nations. World Population Ageing, 2014. Dep Econ Soc Aff Popul Div [Internet]. $2014 ; 73$. Available from: http://books.google.com/books?hl=en\&lr=\&id=9WoK26zWCyIC \&pgis=1

4. Kumar K, Afonso L. Cardiovascular risk prediction in the elderly. J Geriatr Cardiol. 2019;16(5):414-20.

5. Suneja S, Kumawat R, Saxena R. Correlation between hyperuricemia and lipid profile in untreated dyslipidemic patients. Internet J Med Updat - EJOURNAL. 2018;13(1):3-9.

6. Smith E, March L. Global Prevalence of Hyperuricemia: A Systematic Review of PopulationBased Epidemiological Studies - ACR Meeting Abstracts. Arthritis Rheumatol [Internet]. 2015;67(suppl 10). Available from: https://acrabstracts.org/abstract/global-prevalence-ofhyperuricemia-a-systematic-review-of-population-based-epidemiological-studies/

7. Lee Y ho, Lee SG, Lee MH, Kim JH, Lee BW, Kang ES. Serum cholesterol concentration and 
prevalence, awareness, treatment, and control of high low-density lipoprotein cholesterol in the korea national health and nutrition examination surveys 2008-2010: Beyond the tip of the iceberg. J Am Heart Assoc. 2014;3(1):1-13.

8. Thaslima Nandhini JS, Savitha Basker G, Vishnupriya V. Association between serum uric acid and metabolic syndrome. Asian J Pharm Clin Res. 2018;11(10):400-2.

9. Ali N, Rahman S, Islam S, Haque T, Molla NH, Sumon AH. The relationship between serum uric acid and lipid profile in Bangladeshi adults. BMC Cardiovasc Disord. 2019;19(1):1-7.

10. Pourvaghar MJ, Bahram ME, Sayyah M, Khoshemehry S, Wang Y, Meng R-W. Adiponectin, insulin sensitivity and diabetic retinopathy in latinos with type 2 diabetes. J Clin Endocrinol Metab [Internet]. 2016;11(1):3348-55. Available from: http://ejer.org/journal/view.php?number=2013600326\%0Ahttp://search.ebscohost.com/login.aspx?dir ect $=$ true $\& \mathrm{db}=\mathrm{a} 9 \mathrm{~h} \& \mathrm{AN}=99098037 \&$ site $=$ ehost live\%0Ahttp://www.nature.com/articles/s41598-017-18709-9

11. Yang Y, Zhou W, Wang YW, Zhou R. Gender-specific association between uric acid level and chronic kidney disease in the elderly health checkup population in China. Ren Fail [Internet]. 2019;41(1):197-203. Available from: https://doi.org/10.1080/0886022X.2019.1591994

12. Xiu S, Zheng Z, Liao Q, Chan P. Different risk factors for cognitive impairment among community-dwelling elderly, with impaired fasting glucose or diabetes. Diabetes, Metab Syndr Obes Targets Ther. 2019;12:121-30.

13. Chang CC, Wu CH, Liu LK, Chou RH, Kuo CS, Huang PH. Association between serum uric acid and cardiovascular risk in nonhypertensive and nondiabetic individuals: The Taiwan ILan Longitudinal Aging Study. Sci Rep [Internet]. 2018;8(1):1-6. Available from: http://dx.doi.org/10.1038/s41598-018-22997-0

14. Marotta T, Liccardo M, Schettini F, Verde F, Ferrara AL. Association of hyperuricemia with conventional cardiovascular risk factors in elderly patients. J Clin Hypertens. 2015;17(1):2732.

15. Ossei et al. Cause of Death in Diabetics at a Referral Hospital ; A Retrospective Study of 74 Post mortem Cases of 7 Years Duration. ACTA Sci Med Sci. 2019;3(1):54-9.

16. Wolde HF, Atsedeweyen A, Jember A, Awoke T, Mequanent M, Tsegaye AT. Predictors of vascular complications among type 2 diabetes mellitus patients at University of Gondar Referral Hospital: A retrospective follow-up study. BMC Endocr Disord. 2018;18(1):1-8.

17. Fasil A, Biadgo B, Abebe M. Glycemic control and diabetes complications among diabetes mellitus patients attending at University of Gondar Hospital, Northwest Ethiopia. Diabetes, Metab Syndr Obes Targets Ther. 2019;12:75-83. 
18. Chen Q, Yin YJ, Chen WY, Wu JN, Huang X. Assessment of the association between serum uric acid levels and the incidence of hypertension in nonmetabolic syndrome subjects: A prospective observational study. Med (United States). 2018;97(6):1-6.

19. Alvarez C, Saint-Pierre C, Herskovic V, Sepúlveda M. Analysis of the relationship between the referral and evolution of patients with type 2 diabetes mellitus. Int J Environ Res Public Health. 2018;15(7).

20. Fukuhara A, Saito J, Sato S, Saito K, Fukuhara N, Tanino Y. The association between risk of airflow limitation and serum uric acid measured at medical health check-ups. Int J COPD. 2017;12:1213-9.

21. Li Y, Liu S, Gao Y, Ma H, Zhan S, Yang Y. Association between NAFLD and Risk of Colorectal Adenoma in Chinese Han Population. J Clin Transl Hepatol. 2019;7(X):1-7.

22. Wei F, Sun N, Cai C, Feng S, Tian J, Shi W. Associations between serum uric acid and the incidence of hypertension: A Chinese senior dynamic cohort study. J Transl Med. 2016;14(1):1-9.

23. Dai H, Huang Z, Deng Q, Li Y, Xiao T, Ning X. The effects of lead exposure on serum uric acid and hyperuricemia in Chinese adults: A cross-sectional study. Int J Environ Res Public Health. 2015;12(8):9672-82.

24. Susanto N, Kartikasari R, Mendrofa FA. Model Pelatihan Dzikir Pada Persepsi Emosional Dan Spiritual Pada Perawat Di Rumah Sakit ( Studi Kasus Pada Rumah Sakit Keagamaan ) Dhikr Training Model for Emotional and Spiritual Perception of Nurses in Hospital: A Case Study of Religious Hospitals. 2016;1(April):42-52.

25. Tseng WC, Chen YT, Ou SM, Shih CJ, Tarng DC, Yang CY. U-shaped association between serum uric acid levels with cardiovascular and all-cause mortality in the elderly: The role of malnourishment. J Am Heart Assoc. 2018;7(4). 